\title{
An Essential Oil Blend Decreases Methane Emissions and Increases Milk Yield in Dairy Cows
}

\author{
Kenton J. Hart'1,2, Hefin G. Jones', Kate E. Waddams', Hilary J. Worgan1, \\ Beatrice Zweifel ${ }^{3}$, C. Jamie Newbold ${ }^{*}$ \\ ${ }^{1}$ Institute of Biological, Environmental and Rural Sciences (IBERS), Aberystwyth University, Aberystwyth, \\ Ceredigion, UK \\ ${ }^{2}$ Caltech Crystalyx Siloth, Cumbria, UK \\ ${ }^{3}$ Agolin SA, Switzerland \\ ${ }^{4}$ Scotland's Rural College, Kings Buildings, Edinburgh, UK \\ Email: *jamie.newbold@sruc.ac.uk
}

How to cite this paper: Hart, K.J., Jones, H.G., Waddams, K.E., Worgan, H.J., Zweifel, B., and Newbold, C.J. (2019) An Essential Oil Blend Decreases Methane Emissions and Increases Milk Yield in Dairy Cows. Open Journal of Animal Sciences, 9, 259-267.

https://doi.org/10.4236/ojas.2019.93022

Received: April 12, 2019

Accepted: May 6, 2019

Published: May 9, 2019

Copyright $\odot 2019$ by author(s) and Scientific Research Publishing Inc. This work is licensed under the Creative Commons Attribution International License (CC BY 4.0).

http://creativecommons.org/licenses/by/4.0/

\begin{abstract}
This study was conducted to investigate the effect of a commercial essential oil (EO) additive on milk production and methane $\left(\mathrm{CH}_{4}\right)$ emissions from dairy cows. Early lactation Holstein-Friesian dairy cows were fed grass, whole crop wheat and corn silage total mixed ration. Cows were allocated to one of two experimental treatments: Control (no additive, CON) or 1 $\mathrm{g} /$ head/day of EO. Cows were housed in a free stall barn, split into two pens for the duration of the experiment. Two gas data loggers units used to measure $\mathrm{CH}_{4}$ emissions were provided per pen for the duration of the 22 week-long study. Milk yield was determined daily, and milk components were analyzed every two weeks. $\mathrm{CH}_{4}$ was recorded continuously, and daily values were tabulated. Body weight and body condition score were determined at the start and bi-weekly. Results were analyzed as a randomized complete block trial. In total, 149 cows participated in the study $(76 \mathrm{CON}$, $73 \mathrm{EO})$. Milk yields were greater $(\mathrm{P}<0.05)$ for the test treatment $(28.3$ CON, $31.2 \mathrm{EO}$ ) with no change in milk component concentrations. Milk component concentrations were unaffected $(\mathrm{P}>0.05)$ by treatment. Yields of fat, protein, lactose, and solids were higher for EO fed cows $(\mathrm{P}<0.05)$. $\mathrm{CH}_{4}$ output was reduced with the EO compared to the CON treatment (411 $\mathrm{g} /$ day vs $438 \mathrm{~g} /$ day; $13.8 \mathrm{~g} / \mathrm{L}$ of milk vs $17.2 \mathrm{~g} / \mathrm{L}$ of milk, $\mathrm{P}<0.05$ ) over the duration of the trial. There were no effects of treatment on reproductive performance or the occurrence of mastitis. Feeding EO to dairy cows reduced $\mathrm{CH}_{4}$ emissions whilst also increasing performance.
\end{abstract}




\section{Keywords}

Dairy Cows, Essential Oils, Methane, Milk Yield

\section{Introduction}

Agriculture, forestry, and other land uses are responsible for just under a quarter of annual global greenhouse gas (GHG) emissions. Agricultural production accounts for approximately half of these emissions [1] with livestock production being the most important contributing factor within this sector. The largest single contributor to agricultural GHG emissions is methane $\left(\mathrm{CH}_{4}\right)$ produced during enteric fermentation, which represents between $32 \%$ - $40 \%$ of the total GHG emitted from the agricultural sector [1]. Clearly, if the ruminant livestock sector is to continue to flourish and grow, then new technologies must be developed and implemented that allow it to do so while simultaneously decreasing its environmental footprint and maintaining and boosting profitability [2].

Partially in response to the European Union legislation to ban antimicrobial growth promoters in animal production systems and to address concerns over transfer of antibiotic resistance from animals to humans [3] there has been an increased interest in the use of plant extracts to modify rumen fermentation, boost animal production and decrease GHG emissions [4] [5]. Essential oils (EO) are volatile compounds that can be classified as alcohol, ester or aldehyde derivatives of phenylpropanoids and terpenoids [6]. As an active component in many spices and preservatives, EO has been used to inhibit bacterial growth for many years [7]. Highly specific effects on rumen bacteria have been reported [8], with the spectrum of antibacterial effect dependent on the EO used [9], suggesting that they may affect rumen fermentation and potential animal productivity. However, generally trials are either conducted in vitro or of short duration with limited production data available [10].

Agolin Ruminant (Agolin SA, Bière, Switzerland) is a commercially available feed additive classified as a premixture of sensory additives within Europe [11] and approved for use in the United States. The main active compounds within Agolin Ruminant are chemically defined, food grade, plant ingredients including coriander seed oil, geranyl acetate and eugenol. The aim of this experiment was to evaluate the effect of this EO product on the performance of dairy cattle and $\mathrm{CH}_{4}$ emissions from these cows over a longer term basis.

\section{Materials and Methods}

\subsection{Animals and Treatments}

The use of animals within this study was approved by local ethical review under license (European Directive 2010/63/EU). The trial ran from September 2015 to February 2016 using an autumn calving herd. Cows were blocked for parity (primiparous or multiparous), days in milk and previous milk yield prior to be- 
ing randomly allocated to one of two experimental treatments: $0(\mathrm{CON})$ or 1 g/day per head of Agolin Ruminant Liquid Formulation (EO, Agolin SA, Bière, Switzerland). There were 69 cows at the start of the trial, and the remaining animals were added as they calved by week 10 of the 22 -week experiment.

Cows were housed in a well ventilated freestall barn and split by treatment in two halves for the duration of the experiment (Trawscoed Research Farm, Aberystwyth, UK). Animals had free access to feed and water at all times. Cows were offered a total mixed ration (Table 1) formulated for a $620 \mathrm{~kg}$ cow producing $35 \mathrm{~kg}$ milk/day [12] and fed once daily at 9:00 AM each day. The EO was delivered by weighing the appropriate amount of EO (number of animals in treatment group $\times 1 \mathrm{~g}$ ) and diluting to $400 \mathrm{~g}$ with water and mixing onto $25 \mathrm{~kg}$ of feed pellets (LambMaster, Wynnstay Group Plc., Oswestry, UK). The CON was prepared in the same way except that only $400 \mathrm{~g}$ of water was added. The pellets were top dressed on the freshly prepared TMR daily. Sufficient bunk space was available for all cows to access the feed simultaneously. Cows were milked twice daily through a 50-stall rotary parlor at approximately 5:30 and 17:30 during which they received $2.5 \mathrm{~kg}$ dry matter (DM) of a commercial parlor concentrate (Table 1) at each milking. Cows were managed for production and fertility in accordance with standard practice. Incidences of mastitis and pregnancy diagnoses were recorded.

\subsection{Data Collection}

Four, large animal, $\mathrm{CH}_{4}$ monitors (GreenFeed, C-Lock Inc., Rapid City, SD, USA) were distributed within the freestall barn with each treatment group having access to two units. Units supplied dry LambMaster pellets to entice animals into the units. Cows were allocated two feeding bouts of 10 portions $(50 \mathrm{~g})$ during each $12 \mathrm{~h}$ period. Data were only recorded and used in the calculations of $\mathrm{CH}_{4}$ if animals were at the feeder for at least 2 min throughout the day. The $\mathrm{CH}_{4}$ units measured data in real time and produced $10 \mathrm{sec}$ rolling averages; these were then built up over the day and used to predict daily average $\mathrm{CH}_{4}$.

Milk yields were recorded at each milking. Milk samples were taken fortnightly at 2 consecutive milkings and analysed for fat, protein, lactose, and total solids (Delta LactoScope FTIR Advanced, PerkinElmer Inc., UK). Cows were weighed, and condition scored [13] every 2 weeks in the opposing week to milk sampling. Additionally, skin and subcutaneous fat depth were measured to the profound fascia on both sides of the animal in the area between the end of the crista sacralis and the os sacrum [14] using ultrasound (CTS-8800 PlusOrthopedic Ultrasound, SIUI, Guangdong, China). To ensure continuity between measurements, designated members of trained staff made condition scoring and interpretation of ultrasound images.

\subsection{Chemical Analyses}

Analysis of essential oils was determined every two weeks by submitting samples 
Table 1. Ingredient and nutrient composition of feedstuffs.

\begin{tabular}{|c|c|c|}
\hline \multirow{2}{*}{ Dry Matter } & \multicolumn{2}{|c|}{ Feedstuff } \\
\hline & Total Mixed Ration & Parlor Pellets \\
\hline \multicolumn{3}{|l|}{ Ingredient, $\%$} \\
\hline Commercial mix & & 100.0 \\
\hline Grass silage & 34.7 & \\
\hline Wheat silage & 26.0 & \\
\hline Corn silage & 23.8 & \\
\hline Barley grain & 7.0 & \\
\hline Protein blend & 4.9 & \\
\hline Molasses & 2.2 & \\
\hline Fat & 0.6 & \\
\hline Wheat straw & 0.5 & \\
\hline Dairy mineral & 0.3 & \\
\hline \multicolumn{3}{|l|}{ Nutrient, \% } \\
\hline Dry matter,\% & 38.0 & 82.4 \\
\hline Organic matter, $\%$ & 92.6 & 88.3 \\
\hline Gross energy, $\mathrm{Mj} / \mathrm{kg}$ & 16.36 & 14.26 \\
\hline Crude protein, $\%$ & 14.5 & 18.2 \\
\hline NDF, \% & 42.8 & 37.3 \\
\hline $\mathrm{ADF}, \%$ & 24.3 & 15.2 \\
\hline $\mathrm{ADL}, \%$ & 15.6 & 9.4 \\
\hline Fat, \% & 2.7 & 1.9 \\
\hline NFC, $\%$ & 32.6 & 30.9 \\
\hline WSC, \% & 15.2 & 27.3 \\
\hline
\end{tabular}

NDF: Neutral detegent fiber; ADF: Acid detergent fiber; ADL: Acid detergent ligin; NFC: Non fiber carbohydrate; WSC: Water soluble carbohydrate.

of treated and untreated pellets to an external laboratory (CBA GmbH Böhlen, Rötha, Germany). Samples of TMR and parlor concentrate were collected once weekly and combined for analysis. DM was determined after drying at $105^{\circ} \mathrm{C}$ for $24 \mathrm{~h}$. Ash was determined by heating at $550^{\circ} \mathrm{C}$ for $6 \mathrm{~h}$ in a muffle furnace. Nitrogen concentration was measured by the Dumas combustion method (Elementar analyser, Vario MAX cube, Hanau, Germany). For neutral detergent fiber, acid detergent fiber and acid detergent lignin determination, the Automated Fiber Analyzer (ANKOM 2000, Macedon, NY, USA) was used. Fat was determined by solvent extraction using the ANKOM XT15 Extractor (ANKOM, Macedon, NY, USA). Gross energy was determined by bomb calorimetry (IKA C1 calorimeter, Oxford, UK). Water-soluble carbohydrates were determined by spectrometry using anthrone in sulfuric acid [15]. 


\subsection{Statistical Analyses}

Fat corrected (FCM) milk and energy corrected milk (ECM) were computed as described by Erdman [16]. Data were analyzed as a randomized complete block using Minitab 16 statistical software (Minitab Inc., State College. PA, USA) Feed intake was analyzed using a $\mathrm{T}$-test with days used for replication. Incidences of mastitis, as well as fertility data, were analyzed using the $\mathrm{Chi}^{2}$ statistic.

\section{Results and Discussions}

There were 149 cows that participated in the trial. An additional 16 (7 CON and 9 EO) cows that had started the trial were removed over the course of the 22-week study for health reasons not related to treatment, largely mastitis.

Analytic results for the EO concentration of pellets indicated that the level of the additive included in diets was consistently accurate, attaining $98 \%$ to $100 \%$ of target inclusion. Pellets containing the EO treatment were consumed rapidly, and no evidence of exclusion of timid cattle was observed.

\subsection{Milk Production and Composition}

The effects of treatment on milk yield and milk component yield are given in Table 2. Milk yield was greater $(\mathrm{P}<0.05)$ for cows receiving the EO treatment. There were no differences in components on a percentage basis, but component yields were greater for cows receiving the EO treatment. Dry matter intake was increased $(\mathrm{P}<0.05)$ when received the EO treatment.

\subsection{Methane Production}

Although intakes were higher with the EO treatment, total methane production

Table 2. Milk production and milk composition for cows given diets without (CON) or with the inclusion of an essential oil (EO) product for an extended period of time.

\begin{tabular}{cccc}
\hline & \multicolumn{3}{c}{ Treatment } \\
\cline { 2 - 4 } Item & CON & EO & P Value \\
\hline Number of cows & 76 & 73 & \\
Dry matter intake, kg/day & 23.3 & 24.1 & 0.004 \\
Milk yield, kg/day & 28.3 & 31.2 & 0.017 \\
4\% FCM, kg/day & 31.1 & 34.1 & 0.027 \\
ECM, kg/day & 30.7 & 33.6 & 0.029 \\
Components & & & \\
Fat, \% & 4.71 & 4.64 & 0.540 \\
Protein, \% & 3.39 & 3.37 & 0.533 \\
Lactose, \% & 4.77 & 4.74 & 0.277 \\
Total solids, \% & 13.70 & 13.58 & 0.445 \\
Fat, kg/day & 1.32 & 1.44 & 0.046 \\
Protein, kg/day & 0.96 & 1.05 & 0.031 \\
\hline
\end{tabular}


was reduced $(\mathrm{P}<0.05$, Table 3$)$. This suggests that greater quantities of energy would be available both as a result of the greater quantities of feed consumed, and the reduced loss in energy as methane gas. Greater energy availability may have been a factor in greater FCM and ECM in the EO treatment relative to CON.

\subsection{Weight Gain, Body Condition Score (BCS) and Fat Depth}

Table 4 provides data for changes in weight, BCS and fat depth as determined by ultrasound. None of the differences were statistically significant $(\mathrm{P}>0.05)$.

\subsection{Reproduction and Health}

There were no differences in reproductive performance between the two treatment groups (Table 5). As well the occurrences of mastitis were similar between the two treatment groups. It would appear that treatment did not impose differences with respect to these parameters.

\section{Discussion}

There have been two previous trials evaluating this EO blend. In a short-term

Table 3. Methane $\left(\mathrm{CH}_{4}\right)$ production for cows given diets without (CON) or with the inclusion of an essential oil (EO) product for an extended period of time.

\begin{tabular}{cccc}
\hline & \multicolumn{3}{c}{ Treatment } \\
\cline { 2 - 4 } Item & $\mathrm{CON}$ & $\mathrm{EO}$ & P Value \\
\hline $\mathrm{CH}_{4}$ production, g/day & 438.3 & 411.4 & 0.007 \\
$\mathrm{CH}_{4}, \mathrm{~g} / \mathrm{kg}$ milk & 17.2 & 13.8 & $<0.001$ \\
$\mathrm{CH}_{4}, \mathrm{~g} / \mathrm{kg} \mathrm{FCM}$ & 15.6 & 12.7 & $<0.001$ \\
$\mathrm{CH}_{4}, \mathrm{~g} / \mathrm{kg} \mathrm{ECM}$ & 15.8 & 12.9 & $<0.001$ \\
\hline
\end{tabular}

Table 4. Body weight, body condition score (BCS) and tailhead fat depth (FD) for cows given diets without (CON) or with the inclusion of an essential oil (EO) product for an extended period of time.

\begin{tabular}{cccc}
\hline & & Treatment & \\
Item & CON & EO & P Value \\
\cline { 2 - 4 } Start weight, kg & 641.5 & 630.0 & 0.464 \\
End weight, kg & 651.0 & 629.0 & 0.144 \\
Weight change, kg & 9.9 & -1.0 & 0.113 \\
Start BCS, loin & 2.39 & 2.55 & 0.057 \\
End BCS, loin & 2.48 & 2.44 & 0.542 \\
Start BCS, tailhead & 2.41 & 2.50 & 0.126 \\
End BCS, tailhead & 2.50 & 2.40 & 0.188 \\
Start fat depth, mm & 4.99 & 5.29 & 0.134 \\
End fat depth & 4.94 & 4.99 & 0.608 \\
\hline
\end{tabular}


crossover trial with 28 day periods, Santos, et al. [17] reported no treatment effect upon milk yield, but improved milk fat yield. Methane was not measured. Castro-Montoya, et al. [18] reported reduced $\mathrm{CH}_{4}$ production for cows fed EO for a 6 week period. Reduced methane output, as well as greater milk production, was experienced for the duration of this trial. It is possible that an extended period of time is needed to discern treatment differences, and that there might be carry-over effects in trials that use a short period crossover design.

\section{Conclusion}

The current trial clearly showed that methane was reduced: $\mathrm{CH}_{4}$ production was $6 \%$ less per cow per day, and $20 \%$ less per $\mathrm{kg}$ of milk for cows fed EO compared to $\mathrm{CON}$ for the duration of this trial after the initial three weeks (Figure 1). $\mathrm{CH}_{4}$ per kg of milk produced is possibly the more relevant metric given the need to reduce emissions per unit of output [19]. Likewise, it appears that the energy saved through reduced methane output can be used for productive purposes.

Table 5. Reproductive performance and incidence of mastitis for cows given diets without $(\mathrm{CON})$ or with the inclusion of an essential oil (EO) product for an extended period of time.

\begin{tabular}{cccc}
\hline \multirow{2}{*}{ Item } & \multicolumn{3}{c}{ Treatment } \\
\cline { 2 - 4 } & CON & EO & P Value \\
\hline Services/conception & 2.4 & 2.4 & 0.900 \\
Pregnant, \% & 60.5 & 69.9 & 0.468 \\
Clinical Mastitis, number & 17 & 21 & 0.531 \\
Clinical mastitis, \% & 22.4 & 28.7 & 0.531 \\
\hline
\end{tabular}

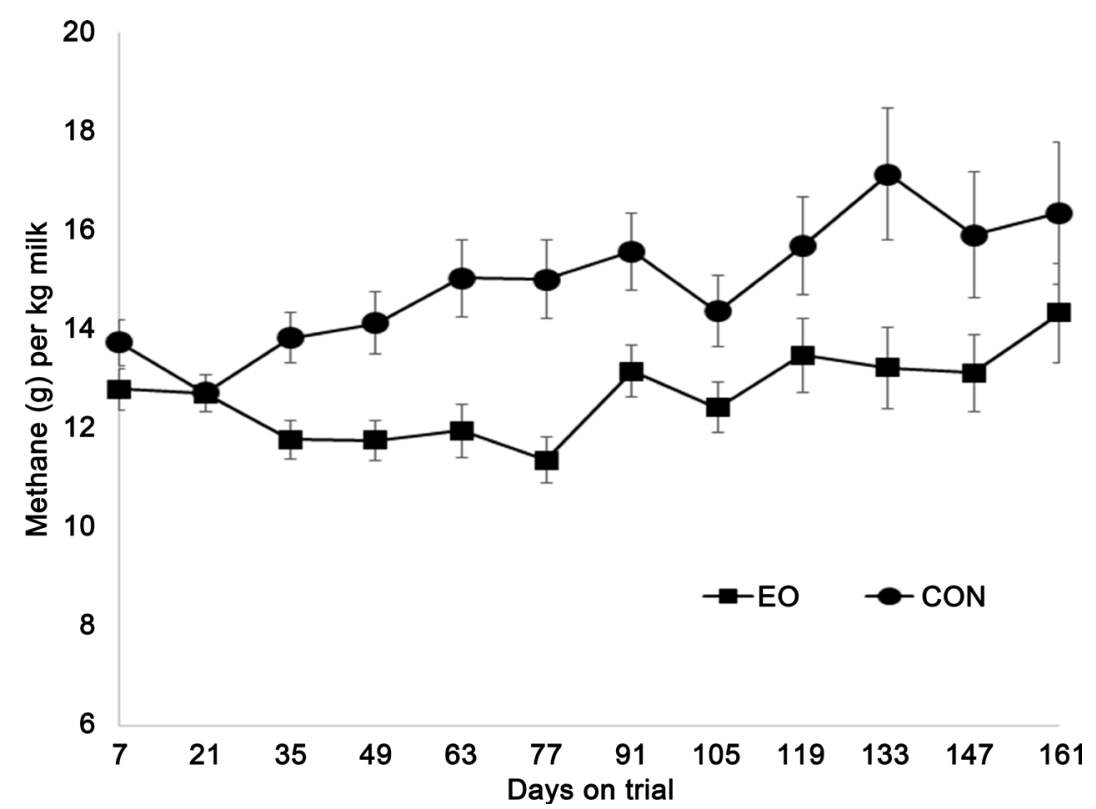

Figure 1. Mean methane per kg of milk of cows receiving EO (squares) or CON (circles). Error bars represent \pm SE. 
Milk yield increased by $3 \mathrm{~kg}$ in this study with no change in component percentages.

\section{Acknowledgements}

This study was funded by Climate KIC as part of the project Reduced Methane Emissions from Ruminants (RuMeClean).

\section{Conflicts of Interest}

Beatrice Zweifel is employed by Agolin SA and was involved in the design but not the interpretation of the trial reported the other authors declare no conflict of interest.

\section{References}

[1] Smith, P., et al. (2014) Agriculture, Forestry and Other Land Use (AFOLU). In: Edenhofer, O., Pichs-Madruga, R., Sokona, Y., Farahani, E., Kadner, S., Seyboth, K., Adler, A., Baum, I., Brunner, S., Eickemeier, P., Kriemann, B., Savolainen, J., Schlömer, S., von Stechow, C., Zwickel, T. and Minx, J.C., Eds., Climate Change 2014: Mitigation of Climate Change, Contribution of Working Group III to the Fifth Assessment Report of the Intergovernmental Panel on Climate Change, Cambridge University Press, Cambridge, 811-922.

[2] Scollan, N.D., Greenwood, P.L. Newbold, C.J., Yáñez, D.R., Shingfield, K.J., Wallace, R.J. and Hocquette, J.F. (2011) Future Research Priorities for Animal Production in a Changing World. Animal Production Science, 51, 1-5.

https://doi.org/10.1071/AN10051

[3] Cabello, F.C. and Godfrey, H.P. (2016) Even Therapeutic Antimicrobial Use in Animal Husbandry may Generate Environmental Hazards to Human Health. Environmental Microbiology, 18, 311-313. https://doi.org/10.1111/1462-2920.13247

[4] Hart, K.J., Yanez-Ruiz, D.R., Duval, S.M., McEwan, N.R. and Newbold, C.J. (2008) Plant Extracts to Manipulate Rumen Fermentation. Animal Feed Science and Technology, 147, 8-35. https://doi.org/10.1016/j.anifeedsci.2007.09.007

[5] Knapp, J.R., Laur, G.L., Vadas, P.A., Weiss, W.P. and Tricarico, J.M. (2014) Invited Review: Enteric Methane in Dairy Cattle Production: Quantifying the Opportunities and Impact of Reducing Emissions. Journal of Dairy Science, 97, 3231-3261. https://doi.org/10.3168/jds.2013-7234

[6] Greathead, H. (2003) Plants and Plant Extracts for Improving Animal Productivity. Proceedings of the Nutrition Society, 62, 279-290. https://doi.org/10.1079/PNS2002197

[7] Hirasa, K. and Takemasa, M. (1998) Antimicrobial and Antioxidant Properties of Spices. Spice Science and Technology. Marcel Dekker, New York. https://doi.org/10.1201/9780585367552

[8] McIntosh, F.M., Williams, P., Losa, R., Wallace, R.J., Beever, D.A. and Newbold, C.J. (2003) Effects of Essential Oils on Ruminal Microorganisms and Their Protein Metabolism. Applied and Environmental Microbiology, 69, 5011-5014. https://doi.org/10.1128/AEM.69.8.5011-5014.2003

[9] Patra, A.K. and Yu, Z. (2015) Essential Oils Affect Populations of Some Rumen Bacteria in Vitro as Revealed by Microarray (RumenBactArray) Analysis. Frontiers in Microbiology, 10, 297. https://doi.org/10.3389/fmicb.2015.00297 
[10] Cobellis, G., Trabalza-Marinucci, M. and Yu, Z. (2016) Critical Evaluation of Essential Oils as Rumen Modifiers in Ruminant Nutrition: A Review. Science of the Total Environment, 545, 556-568. https://doi.org/10.1016/j.scitotenv.2015.12.103

[11] European Commission (2003) Regulation (EC) No 1831/2003 of the European Parliament and of the Council of 22 September 2003 on Additives for Use in Animal nutrition. Official Journal of the European Union, L268, 29-43.

[12] Thomas, C. (2004) Feed into Milk, a New Applied Feeding System for Dairy Cows: An Advisory Manual. Nottingham University Press, Nottingham.

[13] DEFRA (2001) Conditions of Dairy Cows. https://www.gov.uk/government/uploads/system/uploads/attachment_data/file/693 71/pb6492-cattle-scoring-diary020130.pdf

[14] Schröder, U.J. and Staufenbiel, R. (2006) Invited Review: Methods to Determine Body Fat Reserves in the Dairy Cow with Special Regard to Ultrasonographic Measurement of Backfat Thickness. Journal of Dairy Science, 89, 1-14. https://doi.org/10.3168/jds.S0022-0302(06)72064-1

[15] Belanche, A., Lee, M.R.F., Moorby, J.M. and Newbold, C.J. (2013) Comparison of Ryegrass and Red Clover on the Fermentation Pattern, Microbial Community and Efficiency of Diet Utilisation in the Rumen Simulation Technique (Rusitec). Animal Production Science, 53, 1052-1064. https://doi.org/10.1071/AN12183

[16] Erdman, R. (2011) Monitoring Feed Efficiency in Dairy Cows Using Fat-Corrected Milk per Unit of Dry Matter Intake. Proceedings of Mid-Atlantic Nutrition Conference, College Park, 23-24 March 2011, Vol. 9, 69-79.

[17] Santos, M.B., Robinson, P.H., Williams, P. and Losa, R. (2010) Effects of Addition of an Essential Oil Complex to the Diet of Lactating Dairy Cows on Whole Tract Digestion of Nutrients and Productive Performance. Animal Feed Science Technology, 157, 64-71. https://doi.org/10.1016/j.anifeedsci.2010.02.001

[18] Castro-Montoya, T., Peiren, N., Cone, J.W., Zweifel, B., Fievez, V. and De Campeneere, S. (2015) In Vivo and in Vitro Effects of a Blend of Essential Oils on Rumen Methane Mitigation. Livestock Science, 180, 134-142. https://doi.org/10.1016/j.livsci.2015.08.010

[19] Clark, H. (2013) Nutritional and Host Effects on Methanogenesis in the Grazing Ruminant. Animal, 7, 41-48. https://doi.org/10.1017/S1751731112001875 